\section{KINERJA KARYAWAN \\ DALAM MENGEMBANGKAN BISNIS PERIKLANAN}

Buku ini membahas mengenai pengaruh kepemimpinan, budaya organisasi dan motivasi terhadap kinerja karyawan dalam Mengembangkan Bisnis Periklanan pada PT Bangun Selaras.

PT Bangun Selaras adalah perusahaan yang bergerak dalam bidang advertising atau reklame, jasa konstruksi, elektrikal atau mekanikal dan interior contractor. PT Bangun Selaras memanjakan pelanggan dan memberikan layanan advertising satu atap yang terbaik dari ide, perencanaan gambar, produksi, instalasi sampai pajak reklame.

Persaingan usaha di era globalisasi menuntut suatu perusahaan untuk memiliki keunggulan lebih agar dapat bersaing dengan perusahan yang lain. Untuk itu demi kepentingan kemajuan perusahaan, pengelolaan dalam manajemen sumber daya manusia yang tepat dengan semangat kerja yang tinggi serta pemimpin yang efektif dan lingkungan kerja yang mendukung, menjadi kunci suksesnya persaingan di masa pandemic covid-19. Faktor-faktor yang diperlukan dalam untuk meningkatkan kinerja karyawan, diantaranya motivasi dan kepemimpinan. Manajemen kepemimpinan yang tepat memiliki pengaruh dan signifikan terhadap Kinerja, budaya organsiasi memiliki pengaruh dan signifkan terhadap kinerja karyawan, motivasi memiliki pengaruh dan signifikan terhadap kinerja karyawan. Persaingan suatu perusaahan pada masa pandemic covid-19, sangat perlu bagi pimpinan perusahaan dalam mempertahanakan dan meningkatkan kinerja karyawan dengan memikirkan strategi dan identifikasi proses bisnis dalam kondisi covid-19, bergerak cepat dalam mengambil peluang pasar yang memberikan keuntungan bagi perusahaan dan dorongan internal dan eksternal agar kemampuan karyawan dapat memberikan kemampuan yang lebih baik.

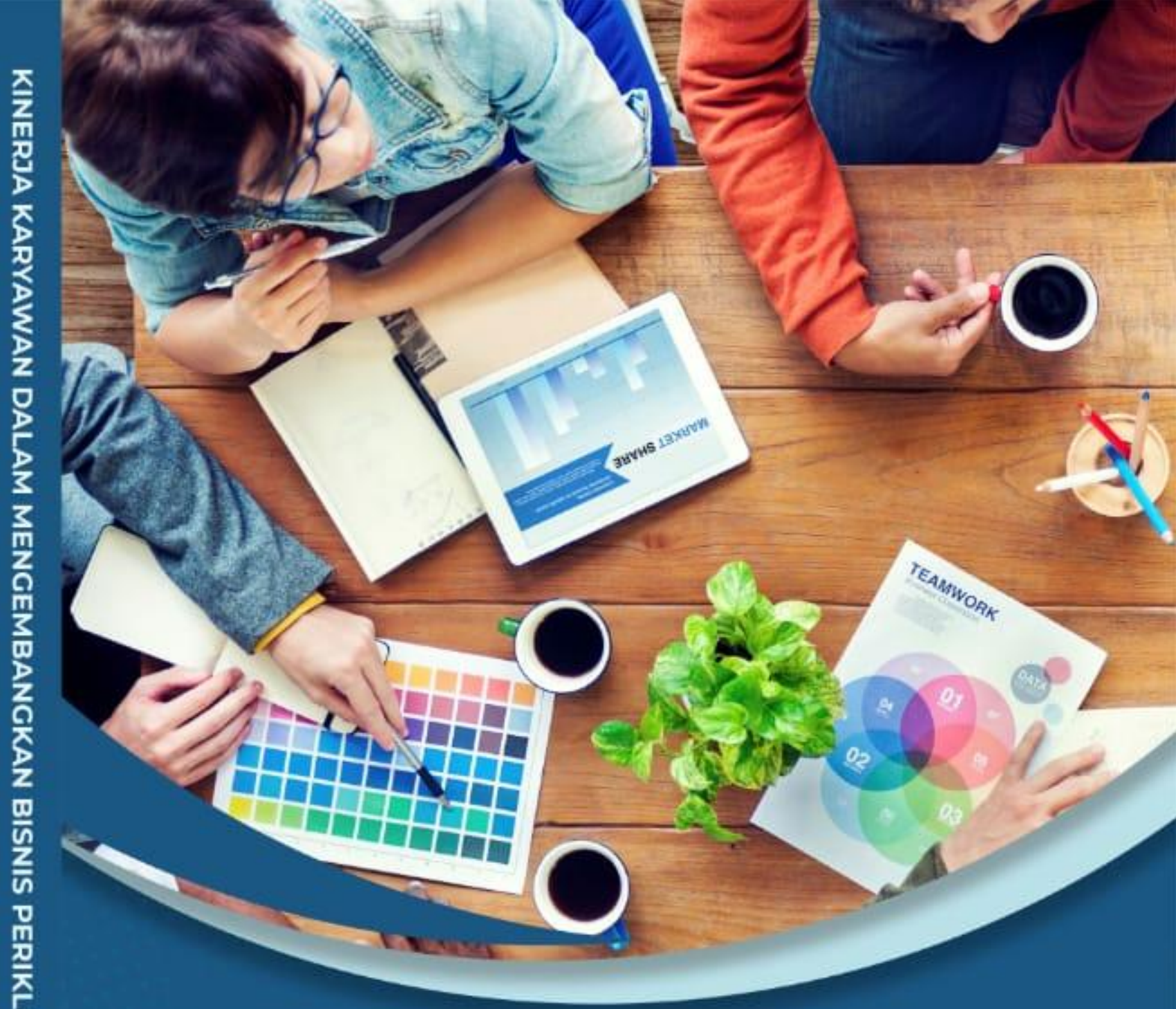

Dr. Nurminingsih, S.Sos, M.Si Cipta Nur Hidayat, SH, M.A.B

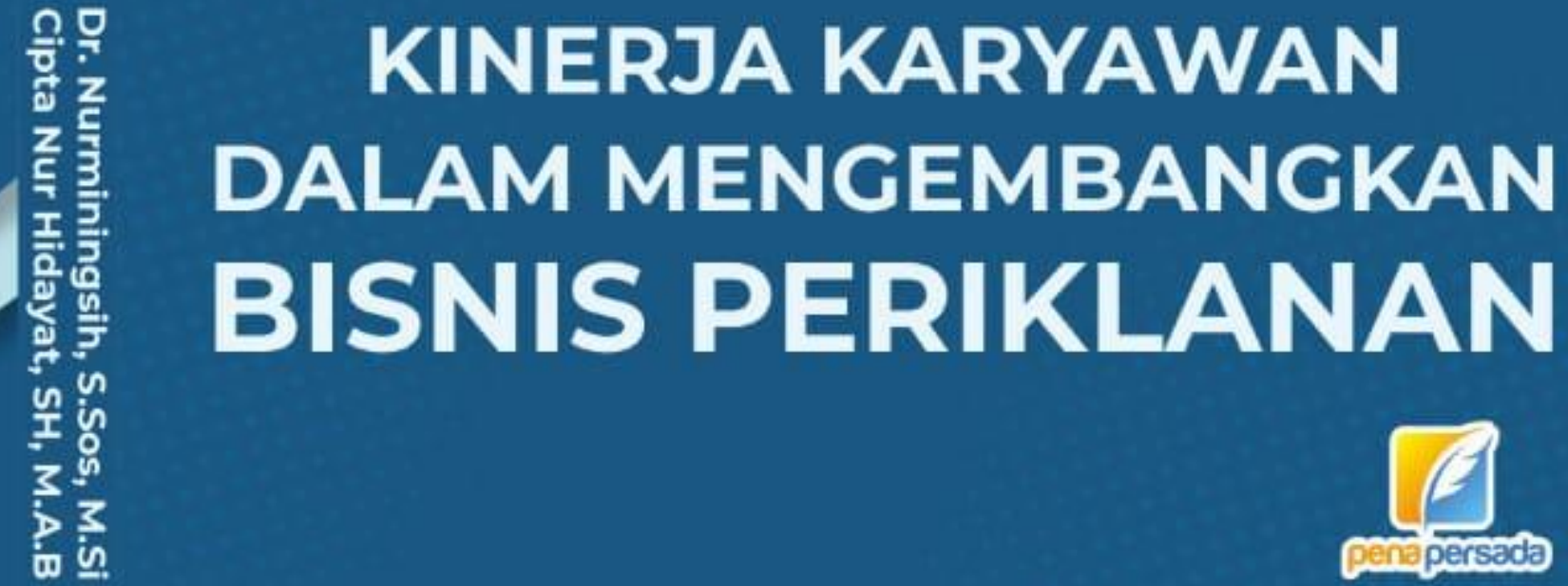




\section{KINERJA KARYAWAN \\ DALAM MENGEMBANGKAN BISNIS PERIKLANAN}

Dr. Nurminingsih, S.Sos, M.Si

Cipta Nur Hidayat, SH, M.A.B

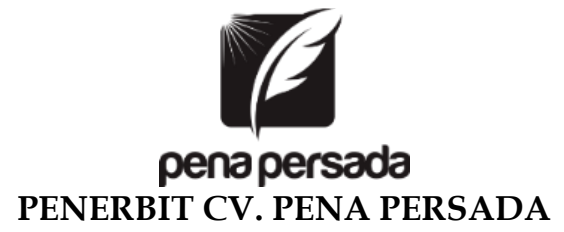




\title{
KINERJA KARYAWAN \\ DALAM MENGEMBANGKAN BISNIS PERIKLANAN
}

\author{
Penulis: \\ Dr. Nurminingsih, S.Sos, M.Si \\ Cipta Nur Hidayat, SH, M.A.B \\ ISBN : 978-623-315-255-6 \\ Editor: \\ Wiwit Kurniawan \\ Design Cover: \\ Retnani Nur Briliant \\ Layout: \\ Hasnah Aulia \\ Penerbit CV. Pena Persada \\ Redaksi : \\ Jl. Gerilya No. 292 Purwokerto Selatan, Kab. Banyumas \\ Jawa Tengah \\ Email: penerbit.penapersada@gmail.com \\ Website: penapersada.com Phone: (0281) 7771388 \\ Anggota IKAPI \\ All right reserved \\ Cetakan pertama: 29 Desember 2021
}

Hak Cipta dilindungi oleh undang-undang. Dilarang memperbanyak karya tulis ini dalam bentuk apapun tanpa izin penerbit 


\section{KATA PENGANTAR}

Segala puji senantiasa kita panjatkan kehadirat Allah Swt, atas segala rahmat dan karunianya, akhirnya penulis dapat menyelesaikan penyusunan buku yang berjudul "KINERJA KARYAWAN DALAM MENGEMBANGKAN BISNIS PERIKLANAN". Saya menyadari bahwa tanpa bantuan dan bimbingan dari berbagai pihak sangatlah sulit bagi saya untuk menyelesaikan karya ini. Oleh karena itu, saya mengucapkan banyak terima kasih pada semua pihak yang telah membantu penyusunan buku ini. Sehingga buku ini bisa hadir di hadapan pembaca.

Dalam buku ini membahas mengenai pengaruh kepemimpinan, budaya organisasi dan motivasi terhadap kinerja karyawan dalam Mengembangkan Bisnis Periklanan pada PT Bangun Selaras. PT Bangun Selaras adalah perusahaan yang bergerak dalam bidang advertising atau reklame, jasa konstruksi, elektrikal atau mekanikal dan interior contractor. PT Bangun Selaras memanjakan pelanggan dan memberikan layanan advertising satu atap yang terbaik dari ide, perencanaan gambar, produksi, instalasi sampai pajak reklame. Hasil kajian menunjukkan bahwa kepemimpinan memiliki pengaruh dan signifikan terhadap Kinerja, budaya organsiasi memiliki pengaruh dan signifkan terhadap kinerja karyawan, motivasi memiliki pengaruh dan signifikan terhadap kinerja karyawan. Sebaiknya pimpinan perusahaan perlu mempertahanakan dan meningkatkan kinerja karyawan dengan memikirkan strategi dan identifikasi proses bisnis dalam kondisi covid-19, bergerak cepat dalam mengambil peluang pasar yang memberikan keuntungan bagi perusahaan dan dorongan internal dan eksternal agar kemampuan karyawan dapat memberikan kemampuan yang lebih baik. 
Penulis menyadari bahwa buku ini masih jauh dari kesempurnaan. Oleh karena itu kritik dan saran yang membangun sangat dibutuhkan guna penyempurnaan buku ini. Akhir kata saya berharap Tuhan Yang Maha Esa berkenan membalas segala kebaikan semua pihak yang telah membantu.

Penulis 


\section{DAFTAR ISI}

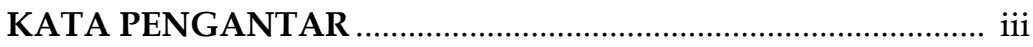

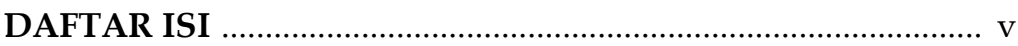

BAB I PENDAHULUAN

A. Persaingan Usaha di Era Globalisasi....................................... 1

B. Faktor-faktor yang Mempengaruhi Perilaku Pegawai ....... 3

\section{BAB II KEPEMIMPINAN}

A. Pengertian Kepemimpinan.................................................. 5

B. Teori Kepemimpinan.......................................................... 6

\section{BAB IIIBUDAYA ORGANISASI}

A. Pengertian Budaya Organisasi ................................................ 10

B. Tingkatan Budaya Organisasi ................................................. 11

C. Dimensi Budaya Organisasi ................................................... 11

BAB IVMOTIVASI KERJA

A. Pengertian Motivasi................................................................. 14

B. Teori Motivasi ..................................................................... 14

C. Teknik Memotivasi Kerja Karyawan..................................... 16

D. Model-Model Motivasi......................................................... 16

E. Tujuan Motivasi ................................................................... 17

F. Faktor yang Mempengaruhi................................................... 18

\section{BAB V KINERJA KARYAWAN}

A. Pengertian Kinerja Karyawan .............................................. 21

B. Pengertian Kinerja Karyawan Menurut Para Ahli ............. 22

C. Tujuan Kinerja Karyawan..................................................... 22

D. Faktor-faktor yang mempengaruhi Kinerja Karyawan ..... 23

E. Dimensi dan Indikator Kinerja Karyawan .......................... 24

BAB VIGAMBARAN PERUSAHAAN PT BANGUN SELARA

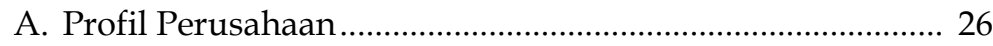

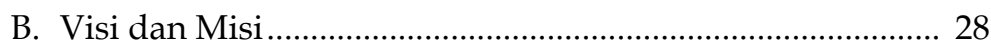

C. Struktur Organisasi PT. Bangun Selaras................................ 28

D. Legalitas Perusahaan........................................................... 29

E. Performa perusahaan PT. Bangun Selaras ............................ 29

F. Deskripsi Obyek .............................................................. 30

1. Karakteristik Jenis Kelamin ................................................. 30

2. Karakteristik Masa Kerja ..................................................... 32 


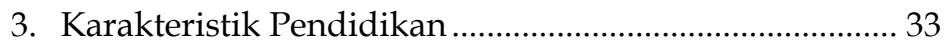

4. Karakteristik Gaji ............................................................... 35

BAB VII KINERJA KARYAWAN PT BANGUN SELARAS

A. Kepemimpinan berpengaruh terhadap Kinerja

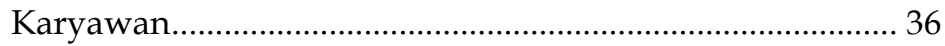

B. Budaya Organisasi berpengaruh terhadap Kinerja

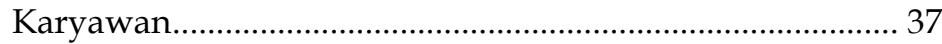

C. Motivasi berpengaruh terhadap Kinerja Karyawan ............. 37

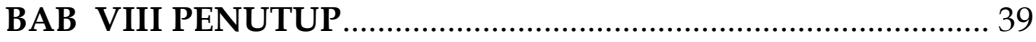

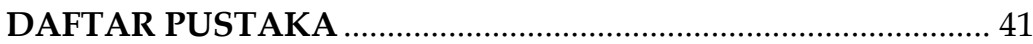

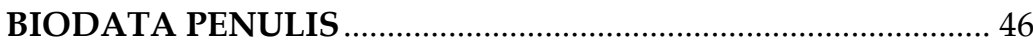




\section{BAB I \\ PENDAHULUAN}

\section{A. Persaingan Usaha di Era Globalisasi}

Era globalisasi mempunyai dampak dalam dunia usaha. Globalisasi menimbulkan persaingan yang ketat diantara perusahaan-perusahaan untuk mendapatkan pangsa pasar yang dibidiknya. Adanya globalisasi maka dunia usaha mau tidak mau didorong untuk mencapai suatu organisasi perusahaan yang efektif dan efisien. Keefektifan dan keefesienan dalam suatu perusahaan sangat diperlukan agar perusahaan dapat memiliki daya saing dan keunggulan lebih dari para pesaing, sehingga perusahaan dapat bertahan dalam dunia persaingan yang ketat.

Dalam bersaing dengan industri yang sejenis lainnya, perusahaan harus mempunyai keunggulan kompetitif yang sangat sulit ditiru, yang hanya akan diperoleh dari karyawan yang produktif, inovatif, kreatif selalu bersemangat dan loyal. Karyawan yang memenuhi kriteria seperti itu hanya akan dimiliki melalui penerapan konsep dan teknik manajemen sumber daya manusia yang tepat dengan semangat kerja yang tinggi serta pemimpin yang efektif dan lingkungan kerja yang mendukung. Faktor-faktor yang dapat digunakan untuk meningkatkan kinerja karyawan, diantaranya motivasi dan kepemimpinan.

Kepemimpinan memiliki peran penting dalam kerangka manajemen. sebab peranan seorang pemimpin pada dasarnya merupakan penjabaran serangkaian fungsi kepemimpinan yaitu untuk mengajak, menghimbau semua bawahan agar dengan penuh kemauan memberikan pengabdian dalam mencapai tujuan organisasi sesuai dengan kemampuan para bawahan secara maksimal. Kepemimpinan dapat dikatakan sebagai salah satu faktor penentu dalam sukses atau gagalnya suatu organisasi. Sebab pemimpin yang sukses mampu mengelola 
organisasi, bisa mempengaruhi orang lain, dan menentukan jalan serta memberikan perilaku benar yang harus dikerjakan bersama-sama.

Pentingnya pemimpin dalam sebuah organisasi terungkap dalam suatu pernyataan berikut: bahwa untuk menunjang keberhasilan fungsi manajemen dalam organisasi tentunya membutuhkan seorang pemimpin yang dapat melaksanakan tugas atau fungsi manajemen (Fikri, 2008). Seorang pemimpin adalah pribadi yang memiliki kecakapan khusus dengan atau tanpa pengangkatan formal dapat mempengaruhi kelompok yang dipimpinnya, untuk melakukan usaha bersama mengarah kepada pencapaian tujuan tertentu (Herispon, 2010).

Keberhasilan sebuah organisasi tergantung pada kepemimpinana dan kualitas sumber daya manusia yang dimiliki organisasi tersebut. Untuk menghasilkan kualitas kerja yang baik dari karyawan maka harus terus ditingkatkan kinerja karyawan tersebut. Pimpinan mempunyai pengaruh untuk memotivasi karyawan agar mempunyai gairah kerja dan meningkatkan semangat kerja. Dalam rangka pencapaian tujuan perusahaan tersebut, maka pengaruh pimpinan terhadap bawahan sangat dibutuhkan untuk tetap mempertahankan dan meningkatkan kinerja karyawan. Kinerja karyawan merupakan hasil atau prestasi kerja yang dicapai seorang karyawan dalam melaksanakan tugasnya dan dihubungkan tugas-tugas rutin yang dikerjakannya. Dengan kata lain, kinerja adalah wujud keberhasilan suatu pekerjaan.

Sementara itu, pendapat lain mengemukakan beberapa faktor mengenai kebutuhan dan keinginan karyawan, yakni gaji yang baik, pekerjaan yang aman, rekan sekerja yang kompak, penghargaan terhadap pekerjaan, pekerjaan yang berarti, kesempatan untuk maju, pimpinan yang adil dan bijaksana, pengarahan dan perintah yang wajar, dan organisasi atau tempat kerja yang dihargai oleh masyarakat. 
Kepemimpinan dan motivasi merupakan kunci utama dalam manajemen yang memegang peran strategis dan penting dalam kelangsungan hidup perusahaan. Pemimpin merupakan pencetus tujuan, merencanakan, menggerakan dan mengorganisasikan seluruh sumber daya yang dimiliki oleh perusahaan dalam rangka mencapai tujuan yang diinginkan.

\section{B. Faktor-faktor yang Mempengaruhi Perilaku Pegawai}

Motivasi kerja merupakan perilaku dan faktor-faktor yang mempengaruhi pegawai untuk berperilaku terhadap pekerjaannya. PT Bangun Selaras memulai karirnya dalam bidang periklanan sejak tergabung dengan beberapa perusahaan periklanan dengan menangani jasa periklanan untuk beberapa client dari perusahaan swasta, nasional hingga instansi pemerintah. Namun di perusahaan tersebut banyak mengalami kendala, yakni terkait dengan kepemimpinan yang kurang mampu mengelola sumber daya manusia dan tanggung jawab karyawan yang belum maksimal, minat karyawan yang rendah sehingga akan mengganggu jalannya perusahaan.

PT.Bangun Selaras, dirintis sejak tahun 2004, pada tahun 2008 dibuat badan hukum usaha dengan nama CV. Seiring dengan perkembangan perusahaan dan memenuhi tuntutan kompetesi pada tahun 2011 status badan usaha ditingkatkan menjadi PT. Perusahaan ini bergerak dalam bidang Advertising/Reklame, Jasa konstruksi, Elektrikal/Mekanikal dan Interior Contractor. PT. Bangun Selaras mempunyai motto "one stop advertising solution" dengan memanjakan pelanggan dan memberikan layanan advertising satu atap yang terbaik mulai dari ide, perencanaan gambar, produksi, instalasi sampai pajak reklame.

Bila perusahaan ingin berhasil dalam mencapai tujuan untuk mendapatkan laba yang layak, berkembang, diakui eksitensinya, maka pihak manajemen di dalam perusahaan tersebut harus terlebih dahulu memberikan perhatian terhadap kesejahteraan atau pembinaan sumber daya manusia yang ada didalamnya. Karena sumber daya manusia adalah asset 
yang paling penting yang berdampak pada perusahaan secara langsung.

PT. Bangun Selaras memiliki VISI menjadi perusahaan yang terbaik dalam memberikan pelayanan dan kepuasan pelanggan, MISI perusahaan mengembangkan sumber daya manusia professional dan bertanggung jawab, menjalin dan menjaga komunikasi dengan costumer sebagai mitra yang saling menguntungkan.

Dalam perkembangan bisnis periklanan perusahaan PT. Bangun Selaras telah berhasil mendapatkan banyak pelanggan perusahaan besar di Indonesia seperti Bank Permata, Bank Mandiri, Bank DKI dan banyak perusahaan lainnya yang telah bekerja sama cukup lama dalam pembuatan produksi iklan yang efektif dan memaksimalkan media digital untuk pemasaran, promosi dan branding produk yang menunjang kemajuan bisnis perusahaan perusahaan yang menjadi pelanggan,

Pada saat peneltiaan PT. Bangun Selaras memiliki kantor dan workshoup di Jl. Merpati Raya ,Murai 2 No.69 Kp Sawah Ciputat, Tanggerang Selatan dengan memiliki seratus karyawan yang bekerja dengan baik, di masa pandemic covid 19 saat ini pimpinan perusahaan mengambil kebijakan untuk bekerja secara WFH work From Home dan WFO work from office untuk mencegah dampak wabah covid 19 yang sangat mempengaruhi bisnis periklanan saat ini. 


\section{BAB II KEPEMIMPINAN}

Kepemimpinan berarti kemampuan dan kesiapan yang dimiliki oleh seseorang untuk dapat mempengaruhi, mendorong, mengajak, menuntun, menggerakan, dan mengarahkan orang atau kelompok agar menerima pengaruh tersebut dan selanjutnya berbuat sesuatu yang dapat membantu tercapainya suatu tujuan tertentu yang telah ditetapkan.

Pada dasarnya kepemimpinan meliputi proses mempengaruhi dalam menentukan tujuan organisasi atau instansi, memotivasi perilaku bawahan untuk mencapai tujuan, mempengaruhi untuk perbaikan kelompok. Hal tersebut dapat dilihat dari keberhasilan seorang pemimpin dalam menggerakan orang lain untuk mencapai tujuan.

\section{A. Pengertian Kepemimpinan}

Kepemimpinan merupakan suatu faktor yang menentukan tercapai atau tidaknya tujuan suatu instansi, dengan kepemimpinan yang baik, proses manajeman akan berjalan lancar dan pegawai bergairah melaksanakan tugastugasnya. Gairah kerja, produktivitas kerja, dan proses manajeman suatu instansi akan baik, jika tipe, cara, atau gaya kepemimpinan yang di terapkan pemimpinnya baik.

keikutsertaan bawahan secara sukarela. Dengan kepemimpinannya, seorang kepala harus bisa menjabarkan arah dan tujuan sebagai target dari sebuah organisasi. Sutikno (2014)."Kepemimpinan dalam organisasi diarahkan untuk mempengaruhi orang-orang yang dipimpinnya, agar mau berbuat seperti yang diharapkan ataupun diarahkan oleh orang lain yang memimpinnya".

Menurut Wahjosumidjo (2014). kepemimpinan diartikan ke dalam istilah sifat- sifat, perilaku individu, punya wibawa pada orang lain, pola- pola, hubungan, komunikasi kerjasama antarperan, pengaruh dari suatu jabatan administratif, 
persuasif, dan pandangan dari yang lain mengenai kewibawaan/pengaruh. Menurut Rivai (2012). kepemimpinan adalah kemampuan seseorang pemimpin untuk mempengaruhi orang lain dengan cara memancing tumbuhnya perasaan yang positif dalam diri orang-orang yang dipimpinnya untuk mencapai tujuan yang diinginkan. Sedangkan menurut Terry George $\mathrm{R}$ yang dialih bahasakan oleh Kartono (2011) kepemimimpinan adalah kegiatan mempengaruhi orang-orang agar mereka suka berusaha mencapai tujuan-tujuan kelompok. Selain itu, menurut Thoha (2011). kepemimpinan adalah kegiatan untuk memengaruhi perilaku orang lain, atau seni memengaruhi perilaku manusia baik perorangan maupun kelompok.

Berdasarkan definisi-definisi di atas maka, dapat disimpulkan bahwa kepemimpinan adalah suatu kegiatan untuk mempengaruhi orang lain dan merubah perilaku untuk mencapai tujuan bersama.

\section{B. Teori Kepemimpinan}

Teori kepemimpinan yang dikemukakan oleh Rivai, Mulyadi (2012) mengemukakan bahwa teori yang berusaha untuk mengidentifikasikan karekteristik khas (fisik, mental, kepribadian) yang dikaitkan dengan keberhasilan kepemimpinan. Teori mengenai kepemimpinan dapat digolongkan kedalam tiga pendekatan utama, yaitu :

1. Pendekatan Sifat

Pendekatan ini menekankan pada kualitas pribadi dari para pemimpin. Pendekatan ini didasarkan pada asumsi bahwa beberapa orang merupakan pemimpin alamiah dan dianugrahi beberapa ciri yang tidak dimiliki orang lain seperti energi yang tidak berkurang, intuisi yang mendalam, pandangan masa depan yang luar biasa, dan kekuatan persuasif yang tidak tertahankan. 
2. Pendekatan Kepribadian Perilaku

Telaah kepemimpinan yang dilakukan pada pusat riset Universitas Michigan, dengan sasaran melokasikan karakteristik perilaku kepimpinan yang tampaknya dikaitkan dengan ukuran kefektifan kinerja, mengidentifikasikan terdapat dua gaya kepemimpinan yang berbeda yaitu:

a. Pemimpin yang berorientasi pada tugas menerapkan pengawasan ketat sehingga bawahan melakukan tugasnya dengan menggunakan prosedur yang telah ditentukan.

b. Pemimpin yang berorientasi pada bawahan mendelegasikan pengambilan keputusan bawahan dan membantu pengikutnya dalam memuaskan kebutuhan nya dengan cara menciptakan lingkungan kerja yang sufortif. Pemimpin yang berpusat pada pegawai memiliki perhatian terhadap kemajuan, pertumbuhan dan prestasi pribadi pengikutnya. Tindakan tindakan ini diasumsikan dapat memajukan pembentukan dan perkembangan kelompok.

3. Pendekatan Kepemimpinan Situasional

Suatu pendekatan terhadap kepemimpinan yang menyatakan bahwa pemimpin memahami perilakunya, sifat-sifat bawahannya, dan situasi sebelum menggunakan satu gaya kepemimpinan tertentu. Pendekatan ini mensyaratkan pemimpin untuik memiliki keterampilan diagnostik dalam perilaku manusia.

\section{Tipe Kepemimpinan}

Kepimpinan di dalam melaksanakan fungsifungsinya, maka akan berlangsung aktivitas kepemimpinan. Apabila aktivitas dapat dicapai dan sesuai dengan rencana maka akan terlihat gaya kepimpinan dengan polanya masing- masing. Rivai (2012) mengemukakan gaya kepemimpinan memiliki tiga pola dasar, yaitu: 

a. Gaya kepimpinan yang berpola pada kepentingan pelaksanaan tugas
b. Gaya kepimpinan yang berpola pada pelaksanaan hubungan kerja sama.
c. Gaya kepemimpinan yang berpola pada kepentingan hasil yang dicapai.

\section{Dimensi dan Indikator Kepemimpinan}

Kepemimpinan yang baik dan efesien sangatlah diperlukan oleh semua perusahaan dalam rangka mencapai suatu tujuannya karena kepemimpinan merupakan kemampuan seseorang mempengaruhi dan memotivasi orang lain untuk melakukan tujuan organisasi. Kepemimpinan meliputi proses mempengaruhi dalam menentukan tujuan organisasi, memotivasi perilaku pengikut untuk mencapai tujuan, mempengaruhi untuk memperbaiki kelompok dan individu. Menurut Gary Yukl (2010), sebagai berikut:

1. Visioner

Pola kemampuan yang ditunjukan untuk memberi arti pada kerja atau usaha yang perlu dilakukan bersama-sama oleh anggota organisasi dengan cara memberi arahan dan makna pada kerja dan usaha yang dilakukan berdasarkan visi yang jelas,dengan pola kemampuan mengarahkan dan arahan visi yang jelas.

2. Pembimbing

Seorang pemimpin yang mampu membimbing bawahannya dengan baik dan mengembangkan keterampilan bawahannya untuk bersama-sama mewujudkan tujuan organisasi.

3. Afiliatif (menggabungkan)

Pemimpin yang bisa menyatukan, mampu menciptakan dan menyelesaikan manajemen konflik dengan baik, menciptakan keharmonisan, mampu mencairkan ketegangan yang terjadi dilingkungan kerja. 
4. Demokratis

Menghargai potensi setiap individu, mau mendengarkan nasihat dan sugesti bawahan, juga bersedia mengakui keahlian para spesialis dengan bidangnya masingmasing.

5. Komunikatif

Kemampuan membangun komunikasi yang baik hubunghan vertical dan hubungan horizontal dalam berbagai kelompok.

Dengan demikiaan yang dimaksud dengan Kepemimpinan adalah kemampuan seorang Direktur untuk mempengaruhi dalam menentukan tujuan perusahaan, memotivasi perilaku karyawan untuk mencapai tujuan yang indikatornya adalah visoner, pembimbing dan demokratis. 


\section{BAB III \\ BUDAYA ORGANISASI}

\section{A. Pengertian Budaya Organisasi}

Luthans (2011) bependapat bahwa: "Budaya organisasi adalah pola pemikiran dasar yang diajarkan kepada personil baru sebagai cara untuk merasakan, berfikir dan bertindak secara benar dari hari kehari".

Druicker mendefinisikan budaya organisasi adalah pokok penyelesaian masalah-masalah eksternal dan internal yang pelaksanaanya dilakukan secara konsisten oleh suatu kelompok yang kemudian mewariskan kepada anggotaanggota baru sebagai cara yang tepat untuk memahami, memikirkan, dan merasakan masalah-masalah terkait.

Sedangkan menurut Moeljono (2003) menyatakan bahwa budaya korporat atau budaya manajemen atau juga dikenal dengan istilah budaya kerja merupakan nilai-nilai dominan yang disebarluaskan didalam organisasi dan diacu sebagai filosofi kerja karyawan.

Gibson, Ivanichevich, dan Donelly berpendapat bahwa budaya organisasi adalah kepribadian organisasi yang mempengaruhi cara bertindak individu dalam organisasi (Soetopo, 2010).

Budaya organisasi merupakan suatu sistem pengertian bersama yang dipegang oleh anggota-anggota suatu organisasi, yang membedakan organisasi tersebut dengan organisasi lainnya (Robbins, 2002).

Dari beberapa definisi diatas dapat disimpulkan bahwa budaya organisasi adalah seperangkat nilai, kepercayaan, falsafah dan pemahaman yang terpola menjadi asumsi-asumsi dasar yang dikembangkan dan dijadikan dasar dalam berperilaku, berpikir, membuat aturan-aturan, pengambilan keputusan serta berbagai masalah organisasional lainnya. 
Budaya organisasi dalam suatu organisasi yang satu dapat berbeda dengan yang ada dalam organisasi yang lain. Namun budaya organisasi menunjukkan ciri-ciri, sifat, atau karakteristik tertentu yang menunjukkan kesamaanya.

\section{B. Tingkatan Budaya Organisasi}

Dalam mempelajari budaya organisasi ada beberapa tingkatan organisasi, dari yang terlihat dalam perilaku (puncak) sampai pada yang tersembunyi (dasar). Apabila disusun dalam sebuah skema bertingkat, topic suatu tingkatan budaya tersebut tersusun dari puncak sebagai berikut : artefak, perspektif, nilai, asumsi (Sucipto dan Siswanto 2008).

Schein (dalam Mohyi, 1999) mengklasifikasikan tingkatan budaya organisasi dalam empat tingkatan, antara lain :

1. Artefak, merupakan aspek-aspek budaya yang terlihat. Artefak lisan, perilaku dan fisik adalah manifestasi nyata dari budaya organisasi.

2. Perspektif, adalah aturan-aturan dan norma yang dapat diaplikasikan dalam konteks tertentu.

3. Nilai, adalah dasar titik berangka evaluasi yang dipergunakan anggota organisasi untuk menilai organisasi, situasi dan hal-hal lain yang ada dalam organisasi.

4. Asumsi, adalah keyakinan yang dimiliki anggota organisasi tentang diri mereka sendiri, tentang orang lain, dan tentang hubungan mereka dengan yang lain serta tentang hakekat organisasi mereka.

\section{Dimensi Budaya Organisasi}

Dimensi mempunyai pengertian yaitu suatu batas yang mengisolir keberadaan suatu eksistensi. Sedangkan indikator adalah variabel yang dapat digunakan untuk mengevaluasi keadaan atau kemungkinan dilakukan pengukuran terhadap perubahan-perubahan yang terjadi dari waktu ke waktu. 
Dimensi dan indikator Budaya Organisasi diuraikan sebagai berikut menurut Edison (2016): sebagai berikut:

1. Kesadaran diri

Anggota organisasi dengan kesadarannya bekerja untuk mendapatkan kepuasan dari pekerjaan mereka, mengembangkan diri, menaati aturan, serta menawarkan produk-produk berkualitas dan layanan tinggi.

2. Keagresifan

Anggota organisasi menetapkan tujuan yang menantang tapi realistis. Mereka menetapkan rencana kerja dan strategi untuk mencapai tujuan tersebut serta mengejarnya dengan antusias.

3. Kepribadian

Anggota bersikap saling membantu menghormati, ramah, terbuka, dan peka terhadap kepuasan kelompok serta sangat memperhatikan aspek-aspek kepuasan pelanggan, baik pelanggan internal maupun eksternal.

4. Performa

Anggota organisasi memiliki nilai kreatifitas, memenuhi kuantitas, mutu, dan efisien. anggota selalu mengutamakan kualitas dalam menyelesaikan pekerjaannya, anggota selalu berinovasi untuk menemukan hal-hal baru dan berguna., setiap anggota selalu berusahan untuk bekerja dengan efektif dan efisien.

5. Orientasi tim

Anggota organisasi melakukan kerjasama yang baik serta melakukan komunikasi dan koordinasi yang efektif dengan keterlibatan aktif para anggota, yang pada gilirannya mendapatkan hasil kepuasan tinggi serta komitmen Bersama, setiap tugas-tugas tim dilakukan dengan diskusi dan disinergikan, setiap ada permasalahan dalam tim kerja selalu diselesaikan dengan baik.

Berdasarkan teori para pakar maka yang dimaksud Budaya Organisasi adalah nilai-nilai dominan yang disebarluaskan didalam perusahaan dan diacu sebagai filosofi 
kerja karyawan yang indikatornya adalah kesadaran diri, keagresifan, kepribadian dan performa. 